\title{
Technical note: Selection of suitable reference genes for studying gene expression in milk somatic cell of yak (Bos grunniens) during the lactation cycle
}

\author{
W. L. Bai, ${ }^{,}$R. H. Yin, ${ }^{\star 1}$ S. J. Zhao,† W. Q. Jiang, ${ }^{\star}$ R. L. Yin,ł Z. J. Ma,§ Z. Y. Wang, ${ }^{\star}$ Y. B. Zhu, ${ }^{\star}$ G. B. Luo, ${ }^{\star}$ \\ R. J. Yang,\# and Z. H. Zhao\# ${ }^{1}$ \\ ${ }^{*}$ College of Animal Science and Veterinary Medicine, Shenyang Agricultural University, Shenyang 110866, China \\ †Institute of Biotechnology, Animal Science Research Academy of Sichuan Province, Chengdu 610066, China \\ ¥Research Academy of Animal Husbandry and Veterinary Medicine Sciences of Jilin Province, Changchun 130062, China \\ $\S$ Academy of Animal Science and Veterinary Medicine, Qinghai University, Xining 810016, China \\ \#College of Animal Science and Veterinary Medicine, Jilin University, Changchun 130062, China
}

\begin{abstract}
Quantitative real-time PCR is the most sensitive technique for gene expression analysis. Data normalization is essential to correct for potential errors incurred in all steps from RNA isolation to PCR amplification. The commonly accepted approach for normalization is the use of reference gene. Until now, no suitable reference genes have been available for data normalization of gene expression in milk somatic cells of lactating yaks across lactation. In the present study, we evaluated the transcriptional stability of 10 candidate reference genes in milk somatic cells of lactating yak, including ACTB, B2M, GAPDH, GTP, MRPL39, PPP1R11, RPS9, RPS15, UXT, and RN18S1. Four genes, RPS9, PPP1R11, UXT, and MRPL39, were identified as being the most stable genes in milk somatic cells of lactating yak. Using the combination of RPS9, PPP1R11, UXT, and MRPL39 as reference genes, we further assessed the relative expression of 4 genes of interest in milk somatic cells of yak across lactation, including ELF5, ABCG2, SREBF2, and DGAT1. Compared with expression in colostrum, the overall transcription levels of ELF5, ABCG2, and SREBF2 in milk were found to be significantly upregulated in early, peak, and late lactation, and significantly downregulated thereafter, before the dry period. A similar pattern was observed in the relative expression of DGAT1, but no significant difference was revealed in its expression in milk from late lactation compared with colostrum. Based on these results, we suggest that the geometric mean of RPS9, PPP1R11, UXT, and MRPL39 can be used for normalization of real-time PCR data in milk somatic cells of lactating yak, if similar experiments are performed.
\end{abstract}

\footnotetext{
Received November 29, 2012.

Accepted October 28, 2013.

${ }^{1}$ Corresponding authors: yinronghuan@163.com and zhzhao@jlu. edu.cn
}

Key words: yak, reference gene, gene expression, milk somatic cell

\section{Technical Note}

Yak (Bos grunniens), a member of the Bovidae family, is found in the mountainous areas of central Asia at altitudes ranging from 2,500 to $5,500 \mathrm{~m}$ ( $\mathrm{Zi}$ et al., 2008). Yak has been reared for multi-purpose use, such as milk, meat, fur, and other products (Ma et al., 2010). Yak milk contains a greater percentage of protein than bovine milk (Wang and Zou, 1995). Although the milk yield of yak is generally low compared with that of the dairy cow, yak milk is important in that it plays an essential role in the diet of local people (Liu et al., 2011).

Quantitative real-time PCR (qPCR) is considered the gold standard for gene expression analyses because of its high sensitivity, specificity, and reproducibility (Yadav et al., 2012). However, the normalization of raw quantity data derived from qPCR is essential to reduce possible errors (Vandesompele et al., 2002). The commonly accepted approach for qPCR data normalization is the use of one or more reference genes (de Jonge et al., 2007; Saremi et al., 2012). In many cases, however, the transcription levels of reference genes have been found to vary with tissue type, developmental stage, and environmental stimuli (Mansur et al., 1993; Janovick-Guretzky et al., 2007; Zheng and Sun, 2011). This variation may ultimately result in misinterpretation of the data obtained from qPCR (Suzuki et al., 2000). Moreover, the applicability of multiple reference genes instead of a single gene is recommended to obtain accurate expression levels of target genes (Peters et al., 2007). Thus, proper evaluation and selection of stable reference genes is crucial before qPCR normalization (Huggett et al., 2005).

Recently, several reference genes were recommended for normalization of $\mathrm{qPCR}$ data in milk somatic cells or lactating mammary gland of cows (Bionaz and Loor, 
2007; Piantoni et al., 2008; Varshney et al., 2012) and buffalo (Yadav et al., 2012). Studies have demonstrated that the relative amount of $\mathrm{mRNA}$ is highly correlated between milk somatic cells and mammary tissue (Boutinaud et al., 2002; Murrieta et al., 2006). No suitable reference gene has yet been identified for normalization of $\mathrm{qPCR}$ data in milk somatic cell of yak during the lactation cycle. Therefore, the purpose of the present work was to identify suitable reference genes for studying gene expression in milk somatic cell of yak during the lactation cycle.

Six adult yaks were selected from Maiwa breed, and sampled for milk (approximately $300 \mathrm{~mL}$ ) from each of 6 individuals at d $3 \pm 1$ (colostrum), $28 \pm 4$ (early lactation), $80 \pm 7$ (peak lactation), $150 \pm 7$ (late lactation), and $180 \pm 7$ (before dry period) after calving, respectively (Bai et al., 2012). The milk samples were transferred to the laboratory in a cooler (at approximately $4^{\circ} \mathrm{C}$ ) within $24 \mathrm{~h}$. The animals sampled in this work had been under veterinary supervision and were healthy in general. Also, they were determined to be free of clinical or subclinical mastitis according to routine testing by SCC [average of 6 animals under study = $(1.264 \pm 0.063) \times 10^{5} / \mathrm{mL}$ in 3 periods, including early, peak, and late periods]. Somatic cell count is a useful predictor of intramammary infection that includes leucocytes (75\%; neutrophils, macrophages, lymphocytes), erythrocytes and epithelial cells (together making up $25 \%$ of the total), as observed in dairy cows (Sharma et al., 2011). Somatic cells from raw milk samples were isolated following the method described by Boutinaud et al. (2002) with minor modification (i.e., somatic cells from raw milk were pelleted by centrifugation at $800 \times$ $g$ for $20 \mathrm{~min}$ at $4^{\circ} \mathrm{C}$ ). The somatic cells isolated were stored in Sample Protector (TaKaRa, Dalian, China) at $-20^{\circ} \mathrm{C}$ until being processed for total RNA extraction.

Total RNA was extracted from isolated somatic cells by using Trizol reagent (Sangon) following the manufacturer's instructions. The integrity of total RNA extracted was verified by $1.5 \%$ agarose gel electrophoresis (Supplementary Figure S1; http://dx.doi. org/10.3168/jds.2012-6437). Using a UV spectrometer, the purity and quantity of the extracted total RNA were assessed, with the optical density (OD) ratio of $\mathrm{OD}_{260} / \mathrm{OD}_{280}$ being 1.8 to 2.0 for all samples. To exclude contamination from residual genomic DNA, we treated the total RNA isolated with DNase I (TaKaRa). Using a Moloney murine leukemia virus cDNA Synthesis Kit (Sangon), the first-strand cDNA was synthesized with $1 \mu \mathrm{g}$ of total RNA for each sample according to the manufacturer's instructions. A negative control (without template RNA) was included for each sample. The cDNA was diluted 1:20 with DNaseand RNase-free water.
A total of 10 candidate reference genes were selected based on the relevant literature (Table 1). Also, ELF5, $A B C G 2, S R E B F 2$, and DGAT1 were used as genes of interest in the present study. Thus, a total of 14 genes were used in this study (Table 1).

Fourteen primer pairs were designed using the Primer Premier 5.0 software (http://www.premierbiosoft.com); primer information is given in Table 1. The specificity of the primer sets designed was confirmed by sequencing analysis of amplicon (Supplementary Table S1; http://dx.doi.org/10.3168/jds.2012-6437).

Using a SYBR Green I assay, qPCR was carried out in a LightCycler 480 Real Time PCR system (Roche Diagnostics, Mannheim, Germany). A 6-point standard curve was generated for each gene by 10 -fold dilution of cDNA. The qPCR was performed in a $20-\mu \mathrm{L}$ final volume containing $10 \mu \mathrm{L}$ of SYBR Premix Ex Taq $(2$ $\times$ concentration; TaKaRa), $0.8 \mu \mathrm{L}$ of forward primer $(10 \mu M), 0.8 \mu \mathrm{L}$ of reverse primer $(10 \mu M), 2.0 \mu \mathrm{L}$ of first-strand cDNA, and $6.4 \mu \mathrm{L}$ of PCR-grade water. The cycling parameters were as follows: $95^{\circ} \mathrm{C}$ for $3 \mathrm{~min}$, and then 40 cycles of the following: $95^{\circ} \mathrm{C}$ for $15 \mathrm{~s}, 51$ to $62^{\circ} \mathrm{C}$ (Table 1 ) for $10 \mathrm{~s}$, and $72^{\circ} \mathrm{C}$ for $20 \mathrm{~s}$. Three replicates were used for each sample for qPCR. The arithmetic mean values from triplicates were obtained for further calculations. A negative control without cDNA template was included in each assay. The data on the expression levels of the 10 candidate reference genes were obtained as quantification cycle $(\mathbf{C q})$ values.

The geNorm algorithm (version 3.5, Vandesompele et al., 2002) was used to evaluate the stability of the 10 candidate reference genes, and to determine the optimal number of reference genes. The qPCR data were exported into an Excel datasheet (Microsoft Corp., Redmond, WA) and $\mathrm{Cq}$ values were converted into raw quantity values (Q) according to the following equation: $\mathrm{Q}=E^{(\text {Min Cq-Sample Cq) }}$, where $E$ is the efficiency of the real time PCR for each gene, and Min Cq is the minimum $\mathrm{Cq}$ value for the samples analyzed.

The validation of the identified suitable genes for normalization was evaluated via detecting the relative expression of 4 genes of interest, including $E L F 5$, $A B C G 2, S R E B F 2$, and DGAT1. The ACTB alone and the geometric mean of PPP1R11, RPS9, UXT, and $M R P L 39$ were used to normalize the expression of the 4 genes of interest (ELF5, ABCG2, SREBF2, and $D G A T 1$ ), respectively. Normalized expression data are reported as the $\log _{2} n$-fold change relative to colostrum time point ( $\mathrm{d} 3$ ). To estimate standard errors at the colostrum time point and prevent biases in statistical analysis, we transformed normalized data to obtain a perfect average of 1.0 at the colostrum time point, leaving the proportional difference between the biological replicates. The same proportional change was 


\begin{tabular}{|c|c|c|c|c|c|c|c|c|c|}
\hline $\begin{array}{l}\text { Gene } \\
\text { symbol }^{1}\end{array}$ & References & $\begin{array}{l}\text { GenBank } \\
\text { accession no. }\end{array}$ & $\begin{array}{l}\text { Primer sequence } \\
\left(5^{\prime} \text { to } 3^{\prime}\right)^{2}\end{array}$ & $\begin{array}{l}\text { Amplicon } \\
\text { size (bp) }\end{array}$ & $\begin{array}{c}\text { Annealing } \\
\text { temperature }\left({ }^{\circ} \mathrm{C}\right)\end{array}$ & $\begin{array}{c}\text { Mean } \\
\mathrm{Cq}^{3}\end{array}$ & Slope $^{4}$ & $\mathrm{R}^{2}$ & $\mathrm{E}^{5}$ \\
\hline$A C T B$ & $\begin{array}{l}\text { Bionaz and Loor, 2007; Yadav et al., } \\
\text { 2012; Varshney et al., } 2012\end{array}$ & DQ838049 & $\begin{array}{l}\text { F: gcaggtcatcaccatcgg } \\
\text { R: ccgtgttggcgtagaggt }\end{array}$ & 158 & 55 & 22.3 & -3.291 & 0.998 & 2.013 \\
\hline B2M & Yadav et al., 2012 & NM_173893 & $\begin{array}{l}\text { F:attctgtttccetgctcttt } \\
\text { R: ttgtcttcccacctctaag }\end{array}$ & 186 & 54 & 17.6 & -3.394 & 0.999 & 1.971 \\
\hline$G A P D H$ & $\begin{array}{l}\text { Bionaz and Loor, 2007; Yadav et al., } \\
\text { 2012; Varshney et al., } 2012\end{array}$ & EU195062 & $\begin{array}{l}\text { F: tgaaccacgagaagtataacaacacc } \\
\text { R: taagtcctccacgatgccaaa }\end{array}$ & 120 & 54 & 23.8 & -3.415 & 0.997 & 1.963 \\
\hline GTP & Bionaz and Loor, 2007 & DQ058609 & $\begin{array}{l}\text { F: gtgatgtccaggattcaggtgt } \\
\text { R: aaggaagtcagccagggtct }\end{array}$ & 165 & 57 & 24.7 & -3.328 & 0.998 & 1.997 \\
\hline MRPL39 & $\begin{array}{l}\text { Bionaz and Loor, 2007; Piantoni et al., } \\
2008\end{array}$ & BC122667 & $\begin{array}{l}\text { F: aaacctttgaccaagtcctgt } \\
\text { R: ttcctctttgaatgccetctc }\end{array}$ & 135 & 55 & 23.1 & -3.352 & 0.995 & 1.988 \\
\hline PPP1R11 & Yadav et al., 2012; Piantoni et al., 2008 & NM_001100295 & $\begin{array}{l}\text { F: cagaaaagacagaagggtgc } \\
\text { R: ttccgaagtttgatggttag }\end{array}$ & 164 & 54 & 28.2 & -3.239 & 0.998 & 2.036 \\
\hline RPS9 & $\begin{array}{l}\text { Bionaz and Loor, 2007; Varshney et al., } \\
2012\end{array}$ & NM_001101152 & $\begin{array}{l}\text { F: acatcccgtccttcatcgtgc } \\
\text { R: cccttcttggcgttcttcctc }\end{array}$ & 115 & 59 & 21.5 & -3.199 & 0.998 & 2.054 \\
\hline$R P S 15$ & $\begin{array}{l}\text { Bionaz and Loor, 2007; Varshney et al., } \\
2012\end{array}$ & BC102068 & $\begin{array}{l}\text { F: gaccttccgcaagttcacct } \\
\text { R: accacctcgggettctccat }\end{array}$ & 198 & 58 & 19.8 & -3.354 & 0.996 & 1.987 \\
\hline$U X T$ & $\begin{array}{l}\text { Bionaz and Loor, 2007; Yadav et al., } \\
\text { 2012; Varshney et al., 2012; Piantoni et } \\
\text { al., 2008 }\end{array}$ & NM_001037471 & $\begin{array}{l}\text { F: aggtggatttgggctgtaac } \\
\text { R: cttggtgaggttgtcgctga }\end{array}$ & 170 & 53 & 24.3 & -3.361 & 0.999 & 1.984 \\
\hline$R N 18 S 1$ & Yadav et al., 2012 & NR_036642 & $\begin{array}{l}\text { F: tttcgatggtagtcgctgtgc } \\
\text { R: ccttggatgtggtagccgttt }\end{array}$ & 102 & 56 & 15.2 & -3.353 & 0.998 & 1.987 \\
\hline$E L F 5$ & Choi et al., 2009; Bionaz and Loor, 2011 & ВТ021517 & $\begin{array}{l}\text { F: tatgctgattccagttgctt } \\
\text { R: accttgttcctatcttcc }\end{array}$ & 168 & 52 & 32.4 & -3.381 & 0.998 & 1.976 \\
\hline$A B C G 2$ & $\begin{array}{l}\text { van Herwaarden et al., 2007; Rudolph et } \\
\text { al., 2007; Bionaz and Loor, } 2008\end{array}$ & ВТ030709 & $\begin{array}{l}\text { F: ctcagtttatccgtggtgtg } \\
\text { R: gagaagatgattgtccgtcc }\end{array}$ & 184 & 53 & 19.2 & -3.333 & 0.996 & 1.995 \\
\hline SREBF2 & Bionaz and Loor, 2008 & NM_001205600 & $\begin{array}{l}\text { F: gcagaccagcacccacactc } \\
\text { R: atgccattcaccagccacag }\end{array}$ & 116 & 59 & 26.4 & -3.428 & 0.992 & 1.958 \\
\hline DGAT1 & $\begin{array}{l}\text { Grisart et al., 2002; Cases et al., 2004; } \\
\text { Bionaz and Loor, } 2008\end{array}$ & NM_174693 & $\begin{array}{l}\text { F: cgggacacagacaaggac } \\
\text { R: gcatcaccacacaccaat }\end{array}$ & 142 & 53 & 29.7 & -3.358 & 0.996 & 1.985 \\
\hline
\end{tabular}

39; $P P P 1 R 11=$ protein phosphatase 1, regulatory subunit 11:RPS9= ribosomal protein S9; $R P S 15=$ ribosomal protein S15; $U X T=$ ubiquitously expressed transcript protein; $R N 18 S 1=18 \mathrm{~S}$ ribosomal RNA; $E L F 5=$ E74-like factor $5 ; A B C G 2=$ ATP-binding cassette, sub-family G (WHITE), member 2; SREBF2 = sterol regulatory element binding transcription factor 2 ; and $D G A T 1=$ diacylolycerol O-acyltransferase 1.

${ }^{2} \mathrm{~A}$ final concentration of $0.4 \mu M$ for each primer was used in the real-time PCR reactions. $\mathrm{F}=$ forward; $\mathrm{R}=$ reverse.

${ }^{3} \mathrm{Cq}=$ quantification cycle.

${ }^{4}$ Slope $=$ slope of standard curve.

${ }^{5}$ Efficiency of real-time PCR, where $\mathrm{E}=10$ (-1/slope). 
calculated in early lactation (d 28), peak lactation (d 80 ), late lactation (d 150), and before dry period (d 180) to obtain a fold change relative to the colostrum time point. This final data set was analyzed by a mixed model in SPSS (SPSS Inc., Chicago, IL) to evaluate the effect of time relative to parturition. The mixed model included the fixed effect of time (d 3, 28, 80, 150, and 180) and the random effect of yak. Means were compared using the Tukey test, and differences between means at the time points investigated were considered to be significant at $P<0.05$. Pearson correlation was performed to assess the relationship between all candidate reference genes $(A C T B, B 2 M, G A P D H$, GTP, MRPL39, PPP1R11, RPS9, RPS15, UXT, and $R N 18 S 1)$ and 4 casein genes (CSN1S1, CSN2, CSN1S2, and CSN3) using SPSS (SPSS Inc.). Differences were considered to be significant when $P<0.05$. The relative expression data for the 4 genes of interest were analyzed with a combination of 4 genes (PPP1R11, RPS9, UXT, and MRPL39) against $A C T B$ alone as reference genes, respectively.

Based on the geNorm analysis, all 10 candidate reference genes exhibited expression stability values ranging from 0.291 to 0.916 , lower than the expression stability threshold of 1.5 accepted by the geNorm algorithm. The PPP1R11 and RPS9 ( $M=0.291)$ genes were identified as the most stable genes in milk somatic cells of lactating yak (Figure 1a), and RN18S1 $(M=0.916)$ was identified as the least stable gene (Figure 1a). As for optimal number of reference genes for expression data normalization, as shown in Figure 1b, the pairwise variation $\left(\mathrm{V}_{3 / 4}\right)$ value 0.151 was very close to the proposed cut-off value 0.15 of geNorm, and the $\mathrm{V}_{4 / 5}$ value 0.131 was less than the cut-off value. These results indicated that a minimum of 4 reference genes (i.e., RPS9, PPP1R11, UXT, and MRPL39) are required for data normalization in milk somatic cells of lactating yak.

The relative expression of ELF5, ABCG2, SREBF2, and DGAT1 are presented in Figure 2. Compared with levels in colostrum, overall, the transcriptional levels of ELF5 (Figure 2a), ABCG2 (Figure 2b), and SREBF2 (Figure 2c) were found to be significantly upregulated in early, peak, and late periods and thereafter significantly downregulated before the dry period. A similar pattern was observed in the relative expression of DGAT1, but no significant difference was found for its expression in late lactation compared with colostrum (Figure 2d). On the other hand, very similar expression patterns were observed for each target gene analyzed when normalized using geometrical mean of the 4 best reference genes (PPP1R11, RPS9, UXT, and MRPL39) or using only $A C T B$ (Figure 2). However, significant differences were observed in the final $\mathrm{qPCR}$ data between the 2 normalization strategies, particularly in early lactation and before the dry period (Figure 2). This indicates that the use of $A C T B$ as the only reference gene would have been inadequate in the present experiment and the use of the geometrical mean of tested reference genes is a better option.

In the present work, a total of 10 candidate reference genes were selected and their expression stabilities were investigated in milk somatic cells of yak during different time points of lactation. When selecting candidate reference genes, the absence of coregulation among the genes chosen is important when the genes are tested using geNorm (Vandesompele et al., 2002; Piantoni et al., 2008). Here, we examined the co-regulation relationships among the candidate reference genes using the Ingenuity Pathway Analysis (Ingenuity Systems, Redwood, CA; www.ingenuity. com). As shown in Supplementary Figure S2 (http:// dx.doi.org/10.3168/jds.2012-6437), we found potential relationships for co-regulation among some of the selected genes under analysis. For instance, GAPDH, $A C T B, U X T$, and RPS9 were shown to be likely subjected to co-regulation by the transcriptional regulator $M Y C$, which plays certain functions in the mammary gland (Happ et al., 1993; Bionaz and Loor, 2007). The existence of potential co-regulations among the genes may limit the accuracy of the geNorm results, which prompted us to further evaluate the transcriptional stability of the 10 candidate reference genes in milk somatic cells of lactating yak using the NormFinder algorithm, which is thought to be unaffected by coregulation relationships among the genes being investigated (Andersen et al., 2004; Varshney et al., 2012). Based on the NormFinder algorithm, the best reference gene in milk somatic cells of lactating yak was $R P S 9$, with a value of 0.214 , whereas the $R N 18 S 1$ gene had the least stable expression with a value of 0.715 (Supplementary Figure S3; http://dx.doi.org/10.3168/ jds.2012-6437). Overall, the ranking of the candidate reference genes was consistent with the results obtained from geNorm analysis. Particularly, we found good agreement between geNorm and NormFinder results regarding the ranking of the 4 most stable genes (PPP1R11, PRS9, UXT, and MRPL39). However, we noted that 2 genes (MRPL39 and PPP1R11) among the 4 best reference genes identified in this study have not demonstrated co-regulation with any of the other tested reference genes (Supplementary Figure S2; http://dx.doi.org/10.3168/jds.2012-6437). Thus, we assumed that the result of geNorm analysis was not biased in the present study. We analyzed potential co-regulation after gene stability was evaluated, which is not a drawback because all genes analyzed as candidate references were previously assumed to be reasonably stable in milk somatic cells or mammary 
(a)

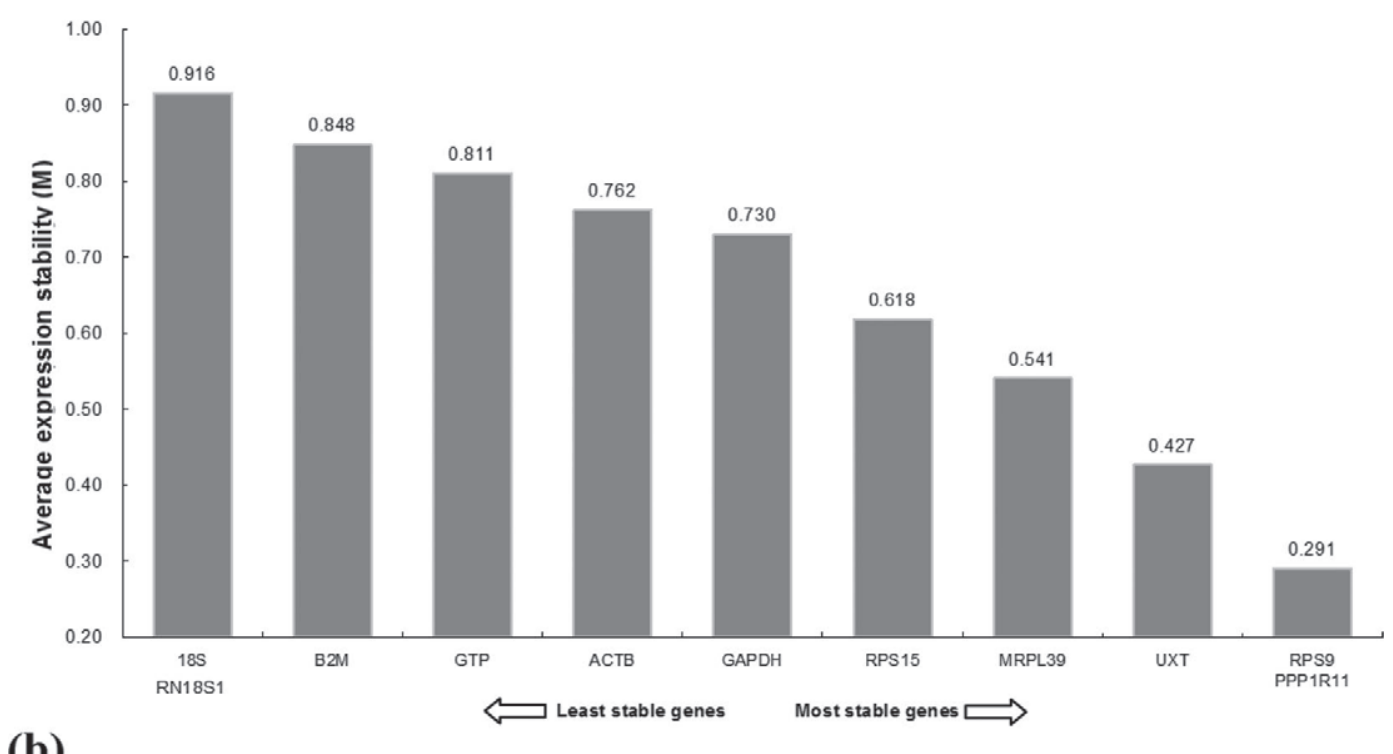

(b)

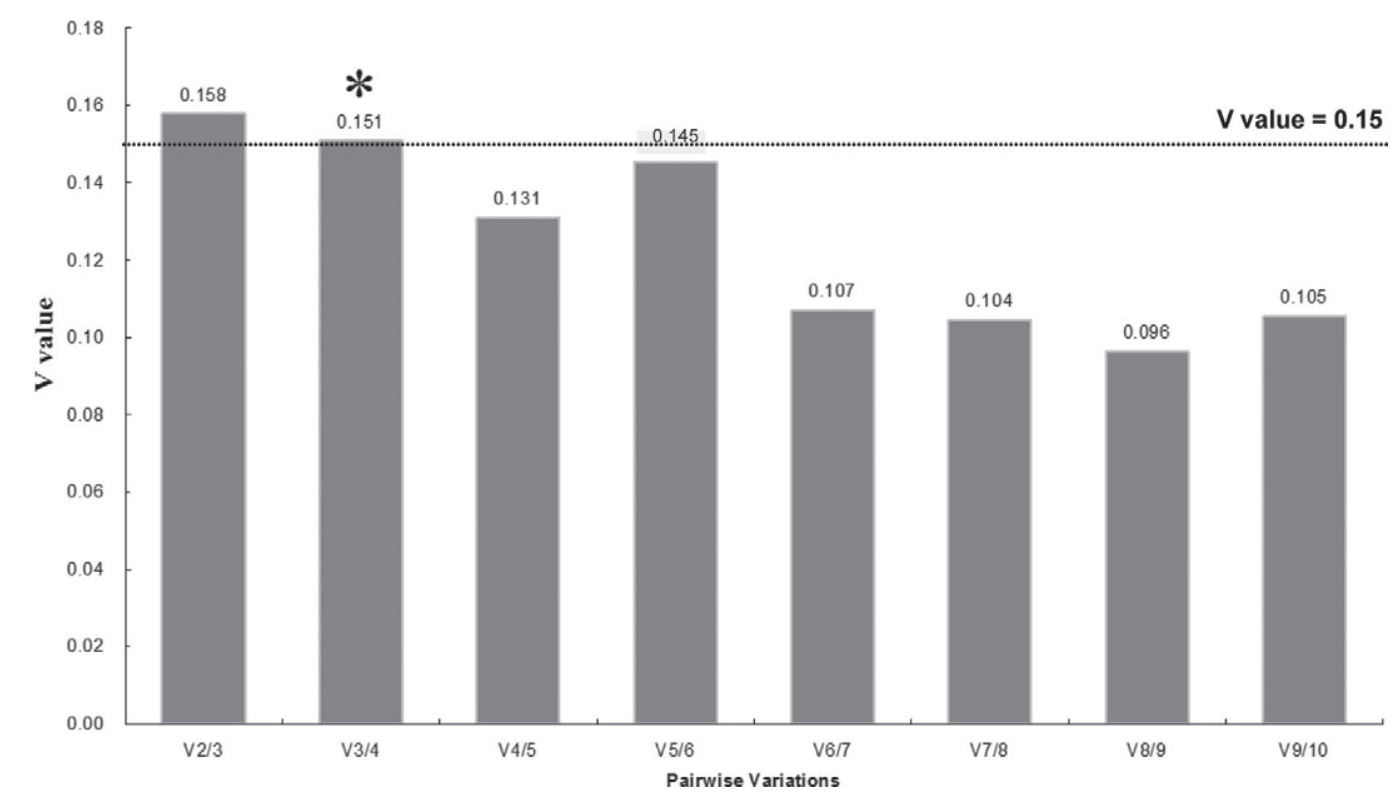

Figure 1. Expression stability analysis of 10 candidate reference genes in milk somatic cells of lactating yak using the geNorm algorithm. (a) Expression stability $(\mathrm{M})$ of the candidate reference genes. A lower $\mathrm{M}$ value = more stable expression; PPP1R11 and RPS9 were determined to be the most stable gene pair. (b) Determination of optimal number of reference genes for expression data normalization by pairwise variation index $(\mathrm{V})$. The $\mathrm{y}$-axis indicates pairwise variation $\mathrm{V}\left(\mathrm{V}_{\mathrm{n} / \mathrm{n}+1}\right)$ between the normalization factors $\mathrm{NF}_{\mathrm{n}}$ and $\mathrm{NF}_{\mathrm{n}+1}$. The asterisk indicates the selected number of reference genes $\left(\mathrm{V}_{3 / 4}=4\right.$ genes $)$ deemed to provide a reliable normalization factor.

gland of cattle and buffalo (Bionaz and Loor, 2007; Varshney et al., 2012; Yadav et al., 2012).

Previously, a dilution effect of tested candidate reference genes was observed in the mammary gland of bovine and swine across lactation (Bionaz and Loor, 2007; Tramontana et al., 2008). In the present study, to evaluate a possible dilution effect of tested candidate reference genes across lactation, we chose 4 casein genes (CSN1S1, CSN2, CSN1S2, and CSN3), whose tran- scriptions are not only abundant in milk somatic cells but also increase markedly from colostrum through peak lactation (unpublished data). Pearson correlation coefficient analysis of raw qPCR data was carried out between all candidate reference genes and the 4 casein genes. However, we did not observe an inverse relationship of any candidate reference genes with any of the 4 casein genes in milk somatic cells across lactation (Supplementary Table S1; http://dx.doi.org/10.3168/ 


\section{(a) ELF5}

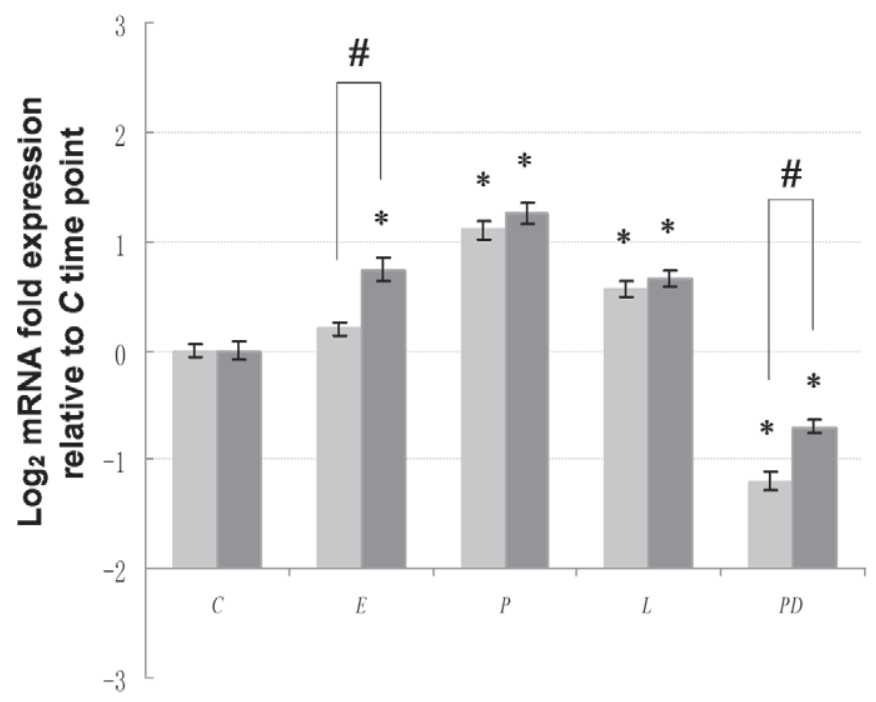

(c) SREBF2

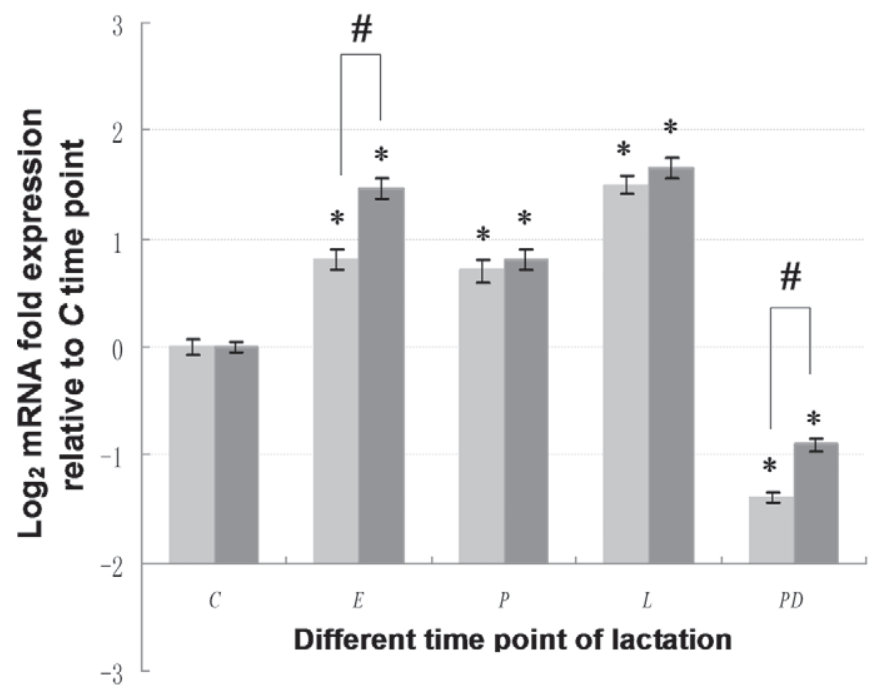

(b) $A B C G 2$

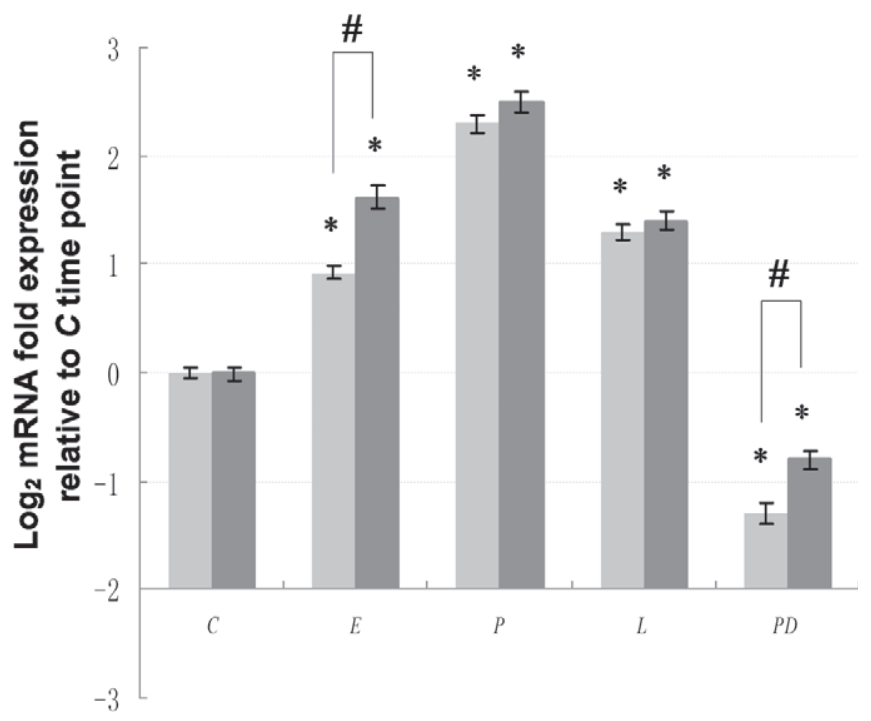

(d) DGAT1

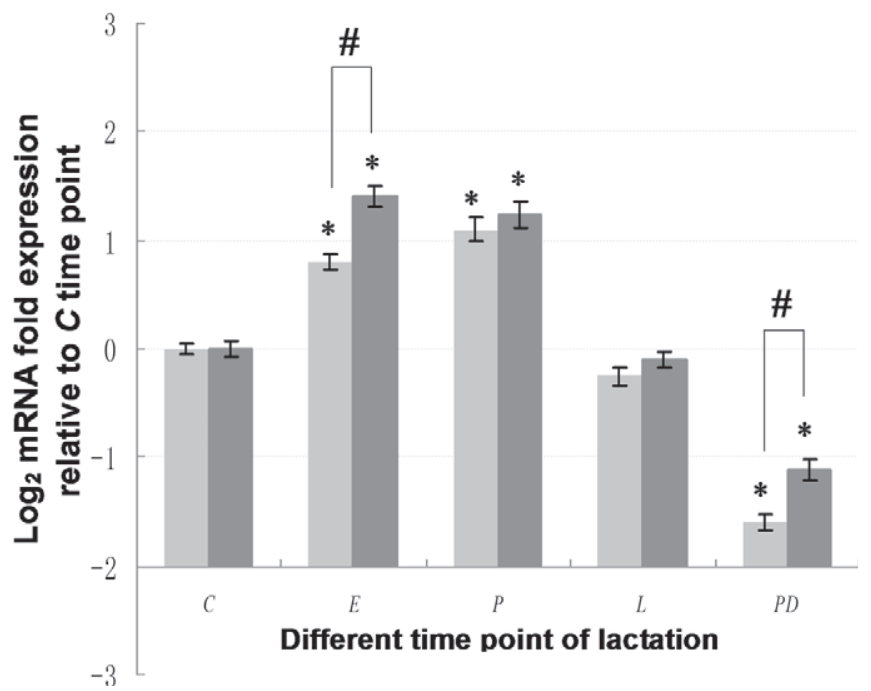

Figure 2. Relative expression of target genes (a) ELF5, (b) ABCG2, (c) SREBF2, and (d) DGAT1 in milk somatic cells of lactating yak across lactation compared with $C$ time point, taking 1 gene $(A C T B)$ and the geometric mean of 4 genes $(R P S 9, P P P 1 R 11, U X T$, and MRPL39) as references. $C=$ colostrum (d 3), $E=$ early period (d 28), $P=$ peak period (d 80), $L=$ late period (d 150$)$, and $P D=$ prior to dry period (d 180). Error bar indicates SEM within the group; * indicates significant difference $(P<0.05)$ compared with $C$ time point; \# indicates significant difference $(P<0.05)$ between $1(A C T B)$ and $4(R P S 9, P P P 1 R 11, U X T$, and MRPL39) references used for normalization at the same time point.

jds.2012-6437), demonstrating that a dilution effect of tested candidate reference genes was absent in this study. More recently, Varshney et al. (2012) also reported a lack of dilution effect of candidate reference genes in milk somatic cells of Bos indicus.

From a theoretical point of view, an optimal reference gene for qPCR should be expressed at a constant level among samples analyzed regardless of the tissue type and physiological condition (Suzuki et al.,
2000). As shown in increasing numbers of investigations, however, no universal reference gene exists: in many cases, expression levels of reference genes vary under different physiological conditions (Mansur et al., 1993; Janovick-Guretzky et al., 2007; Zheng and Sun, 2011). In the present study, RPS9, PPP1R11, UXT, and MRPL39 were determined to be the most stable reference genes in milk somatic cells of lactating yak (Figure 1a). Previous studies have demonstrated that 
RPS9 and UXT have a relatively constant expression in mammary gland in bovine and buffalo during lactation (Bionaz and Loor, 2007; Yadav et al., 2012). Similarly, PPP1R11 has also been reported to be among the best reference genes for normalization of qPCR data in developing mammary tissue (Piantoni et al., 2008) and milk somatic cells in buffalo during lactation (Varshney et al., 2012). Although MRPL39 was the sixth most stable reference gene among 9 genes tested in bovine mammary gland, it had a low $M$ value, and when taken into the pairwise comparison, it produced less variation (Bionaz and Loor, 2007). Similarly, in our study, MRPL39 was identified as the fourth most stable gene in milk somatic cells of lactating yak (Figure 1a).

In some previous studies, RN18S1 was used as a reference gene in gene expression analysis of milk somatic cells and mammary tissue (Murrieta et al., 2006; Sorensen et al., 2006; Thorn et al., 2007). In the present study, RN18S1 mRNA had the lowest stability with a value of 0.916 in geNorm, and was first ruled out as an unstable reference gene. Similarly, $R N 18 S 1$ was reported to be an inappropriate reference gene for data normalization in bovine milk somatic cells across lactation (Varshney et al., 2012). Additionally, GAPDH and $A C T B$ have been used as reference genes for $\mathrm{qPCR}$ data normalization in many investigations (de Jonge et al., 2007; Varshney et al., 2012). However, our results demonstrated that these 2 genes (GAPDH and $A C T B$ ) were inappropriate as normalizers in milk somatic cells of lactating yak, which is consistent with those reported in milk somatic cells of buffalo (Yadav et al., 2012) and mammary gland of cattle (Bionaz and Loor, 2007). In contrast, these results on $G A P D H$ and $A C T B$ from the present work supported the previous finding that expression of $G A P D H$ and $A C T B$ fluctuated dramatically in many cases (de Jonge et al., 2007).

It has been demonstrated that ELF5 has an essential role in expression of milk-related gene, and its expression was thought to be under control of STAT5 (Harris et al., 2006; Hennighausen and Robinson, 2008). In this study, relative to expression in colostrum, the relative expression of ELF5 was significantly upregulated in early, peak, and late lactation. These results were consistent with that reported in bovine mammary gland (Bionaz and Loor, 2011) and supported the previous findings that ELF5 acts as regulator of milk protein synthesis in the mammary gland during lactation (Choi et al., 2009). The $A B C G 2$ gene is a member of the large ATP binding cassette family of membrane-spanning efflux pumps (van Herwaarden et al., 2006). It has been suggested that $A B C G 2$ might have an essential role in secretion of some important milk constituent (van Herwaarden et al., 2006; Bionaz and Loor, 2008), in which the only known role of $A B C G 2$ is for the secretion of ri- boflavin (van Herwaarden et al., 2007). In both bovine and murine mammary gland, the expression of $A B C G 2$ is upregulated across lactation (Rudolph et al., 2007; van Herwaarden et al., 2007). Our results demonstrated that the relative expression of $A B C G 2$ was significantly upregulated in early, peak, and late lactation relative to the colostrum period. Therefore, ABCG2 might perform functions in milk synthesis besides riboflavin secretion (Bionaz and Loor, 2008). We also observed that the expression of $S R E B F 2$ was upregulated during lactation. From a functional point of view, SREBF2 is involved mainly in cholesterol biosynthesis (Eberlé et al., 2004). However, the cholesterol content in milk is low (Bitman et al., 1992) and the majority of milk cholesterol is taken up from serum cholesterol (Long et al., 1980). Therefore, the exact role for the observed upregulation of SREBF2 is unknown. However, SREBF2 might be essential to ensure cholesterol requirements for the formation of milk fat globule membrane (Keenan and Mather, 2006). Data from murine demonstrated that $D G A T 1$ plays important roles in the development of mammary gland and the synthesis of milk (Cases et al., 2004), and DGAT1 is also thought to be a QTL for milk production traits in cattle (Grisart et al., 2002). The pattern of DGAT1 observed in our experiment (Figure 2D) was similar to that observed in bovine mammary tissue (Bionaz and Loor, 2008). Recently, data from the bovine mammary gland suggested that DGAT1 might have an important role in increasing the triacylglycerol content in milk (Bionaz and Loor, 2008). Protein expression and functional analyses should be performed to fully elucidate the role of DGAT1 in secretory activity of the mammary gland during the entire lactation.

In conclusion, we identified $R P S 9, P P P 1 R 11, U X T$, and MRPL39 as the most stable reference genes to normalize qPCR data from milk somatic cells of yak. The set of suggested reliable reference genes is specific only for the present experiment and can be used as such if the same experiment is performed, such as the same yak breed, time points of lactation, and health conditions of sampled animals. If anything changes in the experimental model, we suggest that the proposed reference genes be tested using geNorm or NormFinder to assess their reliability under different experimental conditions.

\section{ACKNOWLEDGMENTS}

We thank the anonymous reviewers for their efforts in further improving this article. This work was supported financially by a grant from Genetically Modified Organisms Breeding Major Projects of China (No.2009ZX08009-156B), National R\&D Project of Transgenic Organisms of Ministry of Sci- 
ence and Technology of China (No. 2011ZX08007-001), the National High Technology Development Project (No. 2013AA102505), and a Foundation for University Talents of Liaoning Province of China (LJQ2013070). R. H. Yin was also supported financially by the Projects of Tianzhushan Person of Outstanding Ability of Shenyang Agricultural University (Shenyang, Liaoning, China).

\section{REFERENCES}

Andersen, C. L., J. L. Jensen, and T. F. Orntoft. 2004. Normalization of real-time quantitative reverse transcription-PCR data: A model-based variance estimation approach to identify genes suited for normalization, applied to bladder and colon cancer data sets. Cancer Res. 64:5245-5250.

Bai, W. L., R. J. Yang, R. H. Yin, W. Q. Jiang, G. B. Luo, R. L. Yin, S. J. Zhao, C. Li, and Z. H. Zhao. 2012. Molecular characterization and expression analysis of osteopontin cDNA from lactating mammary gland in yak (Bos grunniens). Mol. Biol. Rep. 39:3627-3635.

Bionaz, M., and J. J. Loor. 2007. Cycle PCR in the bovine mammary gland during the lactation Identification of reference genes for quantitative real-time PCR in the bovine mammary gland during the lactation cycle. Physiol. Genomics 29:312-319.

Bionaz, M., and J. J. Loor. 2008. Gene networks driving bovine milk fat synthesis during the lactation cycle. BMC Genomics 9:366.

Bionaz, M., and J. J. Loor. 2011. Gene networks driving bovine mammary protein synthesis during the lactation cycle. Bioinform. Biol. Insights 5:83-98.

Bitman, J., D. L. Wood, and A. V. Capuco. 1992. Changes in the lipid composition of the secretions of the bovine mammary gland during the dry period. J. Dairy Sci. 75:435-442.

Boutinaud, M., H. Rulquin, D. H. Keisler, J. Djiane, and H. Jammes. 2002. Use of somatic cells from goat milk for dynamic studies of gene expression in the mammary gland. J. Anim. Sci. 80:12581269.

Cases, S., P. Zhou, J. M. Shillingford, B. S. Wiseman, J. D. Fish, C. S. Angle, L. Hennighausen, Z. Werb, and R. V. Farese Jr. 2004. Development of the mammary gland requires DGAT1 expression in stromal and epithelial tissues. Development 131:3047-3055.

Choi, Y. S., R. Chakrabarti, R. Escamilla-Hernandez, and S. Sinha. 2009. Elf5 conditional knockout mice reveal its role as a master regulator in mammary alveolar development: Failure of Stat5 activation and functional differentiation in the absence of Elf5. Dev. Biol. 329:227-241.

de Jonge, H. J., R. S. Fehrmann, E. S. de Bont, R. M. Hofstra, F. Gerbens, W. A. Kamps, E. G. de Vries, A. G. van der Zee, G. J. te Meerman, and A. ter Elst. 2007. Evidence based selection of housekeeping genes. PLoS ONE 2:e898.

Eberlé, D., B. Hegarty, P. Bossard, P. Ferre, and F. Foufelle. 2004. SREBP transcription factors: Master regulators of lipid homeostasis. Biochimie 86:839-848.

Grisart, B., W. Coppieters, F. Farnir, L. Karim, C. Ford, P. Berzi, N. Cambisano, M. Mni, S. Reid, P. Simon, R. Spelman, M. Georges, and R. Snell. 2002. Positional candidate cloning of a QTL in dairy cattle: Identification of a missense mutation in the bovine DGAT1 gene with major effect on milk yield and composition. Genome Res. 12:222-231.

Happ, B., N. E. Hynes, and B. Groner. 1993. Ha-Ras and V-Raf oncogenes, but not Int-2 and C-Myc, interfere with the lactogenic hormone dependent activation of the mammary-gland specific transcription factor. Cell Growth Differ. 4:9-15.

Harris, J., P. M. Stanford, K. Sutherland, S. R. Oakes, M. J. Naylor, F. G. Robertson, K. D. Blazek, M. Kazlauskas, H. N. Hilton, S. Wittlin, W. S. Alexander, G. J. Lindeman, J. E. Visvader, and C. J. Ormandy. 2006. Socs2 and elf5 mediate prolactin-induced mammary gland development. Mol. Endocrinol. 20:1177-1187.
Hennighausen, L., and G. W. Robinson. 2008. Interpretation of cytokine signaling through the transcription factors STAT5 A and STAT5B. Genes Dev. 22:711-721.

Huggett, J., K. Dheda, S. Bustin, and A. Zumla. 2005. Real-time RTPCR normalization; strategies and considerations. Genes Immun. 6:279-284.

Janovick-Guretzky, N. A., H. M. Dann, D. B. Carlson, M. R. Murphy, J. J. Loor, and J. K. Drackley. 2007. Housekeeping gene expression in bovine liver is affected by physiological state, feed intake, and dietary treatment. J. Dairy Sci. 90:2246-2252.

Keenan, T. W., and I. H. Mather. 2006. Intracellular origin of milk fat globules and the nature of the milk fat globule membrane. Pages 137-171 in Advanced Dairy Chemistry: Lipids 2. P. F. Fox and P L. H. McSweeney, ed. Springer, New York, NY.

Liu, H. N., F. Z. Ren, L. Jiang, Z. L. Ma, H. J. Qiao, S. S. Zeng, B. Z. Gan, and H. Y. Guo. 2011. Fatty acid profile of yak milk from the Qinghai-Tibetan Plateau in different seasons and for different parities. J. Dairy Sci. 94:1724-1731.

Long, C. A., S. Patton, and R. D. McCarthy. 1980. Origins of the cholesterol in milk. Lipids 15:853-857.

Ma, Z. J., J. T. Xu, J. C. Zhong, Q. L. Dou, Y. G. Sun, and Y. Ma. 2010. Structural features of the $5^{\prime}$ flanking region of the yak (Bos grunniens) growth hormone receptor (GHR) gene. Arch. Tierzucht. $53: 372-376$.

Mansur, N. R., K. Meyer-Stegler, J. C. Wurtz, and M. A. Sirover. 1993. Cell cycle regulation of the glyceraldehydes-3-phosphate dehydrogenase/uracil glycosylase gene in normal human cell. Nucleic Acids Res. 21:993-998.

Murrieta, C. M., B. W. Hess, E. J. Scholljegerdes, T. E. Engle, K. L. Hossner, and G. E. Moss. 2006. Evaluation of milk somatic cells as a source of mRNA for study of lipogenesis in the mammary gland of lactating beef cows supplemented with dietary high-linoleate safflower seeds. J. Anim. Sci. 84:2399-2405.

Peters, I. R., D. Peeters, C. R. Helps, and M. J. Day. 2007. Development and application of multiple internal reference (housekeeper) gene assays for accurate normalisation of canine gene expression studies. Vet. Immunol. Immunopathol. 117:55-66.

Piantoni, P., M. Bionaz, D. E. Graugnard, K. M. Daniels, R. M. Akers, and J. J. Loor. 2008. Gene expression ratio stability evaluation in prepubertal bovine mammary tissue from calves fed different milk replacers reveals novel internal controls for quantitative polymerase chain reaction. J. Nutr. 138:1158-1164.

Rudolph, M. C., J. L. McManaman, T. Phang, T. Russell, D. J. Kominsky, N. J. Serkova, T. Stein, S. M. Anderson, and M. C. Neville. 2007. Metabolic regulation in the lactating mammary gland: A lipid synthesizing machine. Physiol. Genomics 28:323-336.

Saremi, B., H. Sauerwein, S. Dänicke, and M. Mielenz. 2012. Identification of reference genes for gene expression studies in different bovine tissues focusing on different fat depots. J. Dairy Sci. 95:3131-3138.

Sharma, N., N. K. Singh, and M. S. Bhadwal. 2011. Relationship of somatic cell count and mastitis: An overview. Asian-australas. J. Anim. Sci. 24:429-438.

Sorensen, M. T., J. V. Norgaard, P. K. Theil, M. Vestergaard, and K. Sejrsen. 2006. Cell turnover and activity in mammary tissue during lactation and the dry period in dairy cows. J. Dairy Sci. 89:4632-4639.

Suzuki, T., P. J. Higgins, and D. R. Crawford. 2000. Control selection for RNA quantitation. Biotechniques 29:332.

Thorn, S. R., M. J. Meyer, M. E. Van Amburgh, and Y. R. Boisclair. 2007. Effect of estrogen on leptin and expression of leptin receptor transcripts in prepubertal dairy heifers. J. Dairy Sci. 90:3742-3750.

Tramontana, S., M. Bionaz, A. Sharma, D. E. Graugnard, E. A. Cutler, P. Ajmone-Marsan, W. L. Hurley, and J. J. Loor. 2008. Internal controls for quantitative polymerase chain reaction of swine mammary glands during pregnancy and lactation. J. Dairy Sci. 91:3057-3066.

van Herwaarden, A. E., E. Wagenaar, B. Karnekamp, G. Merino, J. W. Jonker, and A. H. Schinkel. 2006. Breast cancer resistance 
protein (Bcrp1/Abcg2) reduces systemic exposure of the dietary carcinogens aflatoxin B1, IQ and Trp-P-1 but also mediates their secretion into breast milk. Carcinogenesis 27:123-130.

van Herwaarden, A. E., E. Wagenaar, G. Merino, J. W. Jonker, H Rosing, J. H. Beijnen, and A. H. Schinkel. 2007. Multidrug transporter ABCG2/breast cancer resistance protein secretes riboflavin (vitamin B2) into milk. Mol. Cell. Biol. 27:1247-1253.

Vandesompele, J., K. De Preter, F. Pattyn, B. Poppe, N. Van Roy A. De Paepe, and F. Speleman. 2002. Accurate normalization of real-time quantitative RT-PCR data by geometric averaging of multiple internal control genes. Genome Biol. 3:research0034.1research0034.11. http://dx.doi.org/10.1186/gb-2002-3-7-research 0034 .

Varshney, N., A. K. Mohanty, S. Kumar, J. K. Kaushik, A. K. Dang, M. Mukesh, B. P. Mishra, R. Kataria, S. P. Kimothi, T. K. Mukhopadhyay, D. Malakar, B. S. Prakash, S. Grover, and V. K. Batish. 2012. Selection of suitable reference genes for quantitative gene expression studies in milk somatic cells of lactating cows (Bos indicus). J. Dairy Sci. 95:2935-2945.

Wang, Y. S., and S. X. Zou. 1995. Protein in milk. Pages 1-48 in Biochemistry of Milk. Jilin Univ. Press, Changchun, China.

Yadav, P., D. D. Singh, M. Mukesh, R. S. Kataria, A. Yadav, A. K. Mohanty, and B. P. Mishra. 2012. Identification of suitable housekeeping genes for expression analysis in mammary epithelial cells of buffalo (Bubalus bubalis) during lactation cycle. Livest. Sci. $147: 72-76$

Zheng, W. J., and L. Sun. 2011. Evaluation of housekeeping genes as references for quantitative real time RT-PCR analysis of gene expression in Japanese flounder (Paralichthys olivaceus). Fish Shellfish Immunol. 30:638-645.

Zi, X. D., H. Lu, R. H. Yin, and S. W. Chen. 2008. Development of embryos after in vitro fertilization of bovine oocytes with sperm from either yaks (Bos grunniens) or cattle (Bos taurus). Anim. Reprod. Sci. 108:208-215. 